\title{
Correction Notice to: Technical mitigation measures for sharks and rays in fisheries for tuna and tuna-like species: turning possibility into reality
}

\section{Aquat. Living Resour. 29, 402 (2016), DOI: 10.1051/alr/2016030}

François Poisson ${ }^{1, a}$, Francisco Abascal Crespo ${ }^{2,8}$, Jim R. Ellis ${ }^{3}$, Pierre Chavance ${ }^{4}$, Pascal Bach ${ }^{4}$, Miguel N. Santos ${ }^{5}$, Bernard Séret ${ }^{6}$, Maria Korta ${ }^{7}$, Rui Coelho ${ }^{8}$, Javier Ariz ${ }^{2}$ and Hilario Murua ${ }^{7}$

${ }^{1}$ Institut Français de Recherche pour l'Exploitation de la Mer (Ifremer), UMR Marbec, CS 30171, Avenue Jean Monnet, 34203 Sète Cedex, France

2 Instituto Español de Oceanografía, PO Box 1373, 38180 Santa Cruz de Tenerife, Spain

${ }^{3}$ Centre for Environment, Fisheries and Aquaculture Science (CEFAS), Lowestoft Laboratory, Pakefield Road, Lowestoft, Suffolk, NR33 0HT, UK

${ }^{4}$ Institut de Recherche pour le Développement (IRD), UMR Marbec, CS 30171, Avenue Jean Monnet, 34203 Sète Cedex, France

5 ICCAT Secretariat, Calle Corazón de Maria 8, 6 planta, 28002 Madrid, Spain

${ }^{6}$ Institut de Recherche pour le Développement (IRD), UMR 212, Muséum national d'Histoire Naturelle Département Systématique et Evolution, CP 51, 55 rue Buffon, 75231 Paris Cedex 05, France

7 AZTI, Herrera Kaia, Portualde z/g, 20110 Pasaia (Gipuzkoa), Spain

${ }^{8}$ Instituto Português do Mar e da Atmosfera (IPMA), Avenida 5 de Outubro s/n, 8700-305 Olhão, Portugal

Received 17 October 2019 / Accepted 18 October 2019

An error occurred in article "Technical mitigation measures for sharks and rays in fisheries for tuna and tuna-like species: turning possibility into reality" published in Volume 29, 402 (2016). The first name and last name of the author "Pascal Bach" were reversed in previous version.

This correction notice provides the correct online file. Publisher apologizes for the inconvenience. 